\title{
Dietary acid load and cardiometabolic risk in the Polish adult population
}

\author{
Alicja M. Kucharska*1,A,C-F, Dorota E. Szostak-Węgierek ${ }^{* 2, A, C-F}$, Anna Waśkiewicz ${ }^{* 3, A-F}$,

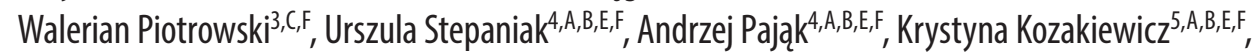 \\ Andrzej Tykarski, ${ }^{6, A, B, E, F}$, Marcin Rutkowski, ${ }^{, A, B, E, F}$, Wojciech J. Bielecki, ${ }^{8, A, B, E, F}$, Wojciech Drygas 3 ,A,B,E,F \\ ${ }^{1}$ Department of Human Nutrition, Faculty of Health Science, Medical University of Warsaw, Poland \\ ${ }^{2}$ Department of Clinical Dietetics, Medical University of Warsaw, Poland \\ ${ }^{3}$ Department of Epidemiology, Cardiovascular Disease Prevention and Health Promotion, National Institute of Cardiology, Warszawa, Poland \\ ${ }^{4}$ Department of Epidemiology and Population Studies, Institute of Public Health, Faculty of Health Sciences, Jagiellonian University Medical College, Kraków, Poland

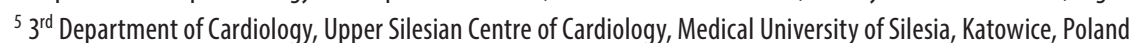 \\ ${ }^{6}$ Department of Hypertension, Angiology and Internal Medicine, Poznan University of Medical Sciences, Poland \\ ${ }^{7}$ Department of Arterial Hypertension and Diabetology, Medical University of Gdansk, Poland \\ ${ }^{8}$ Department of Social and Preventive Medicine, Medical University of Lodz, Poland \\ A - research concept and design; B - collection and/or assembly of data; $C$ - data analysis and interpretation; \\ $\mathrm{D}$ - writing the article; $\mathrm{E}$ - critical revision of the article; $\mathrm{F}$ - final approval of the article
}

Address for correspondence

Dorota E. Szostak-Węgierek

E-mail: dszostak-wegierek@wp.pl

${ }^{*}$ These authors contributed equally to this work

\section{Funding sources}

WOBASZ II project was financed from the financial resources at the disposal of the Minister of Health within the framework of the health program entitled: National Program of Equalization the Accessibility to Cardiovascular Disease Prevention and Treatment for 2010-2012 POLKARD - goal: Analyses and epidemiology - "Monitoring of the epidemiological situation in Poland in the field of cardiovascular diseases".

\section{Conflict of interest}

None declared

\section{Acknowledgements}

Authors express special thanks to the research team and collaborating persons from the field centers in 16 voivodeships, and to all participants of the WOBASZ and WOBASZ II studies.

Received on January 10, 2017

Reviewed on February 5, 2017

Accepted on March 24, 2017

DOI

10.17219/acem/69733

\section{Copyright}

Copyright by Author(s)

This is an article distributed under the terms of the Creative Commons Attribution Non-Commercial License (http://creativecommons.org/licenses/by-nc-nd/4.0/)

\section{Abstract}

Background. The potential influence of disorders of acid/base homeostasis on cardiovascular risk factors has been suggested.

Objectives. The aim of the study was to estimate the relationship between dietary acid load and the prevalence of cardiovascular disease and the prevalence and intensity of cardiovascular risk factors (i.e., hypertension, diabetes, overweight and obesity, dyslipidemia) in the Polish adult population.

Material and methods. Data was derived from a cross-sectional survey of a random sample of 6170 Polish residents aged 20+ (Multi-Center National Population Health Examination Survey, WOBASZ II study), including anthropometric and laboratory measurements, and estimates of nutrient intakes by 24-hour recall. Dietary acid/base load was assessed as potential renal acid load (PRAL) and net endogenous acid production (NEAP).

Results. The median PRAL and NEAP values for the whole study population were: PRAL $-3.85 \mathrm{mEg} / \mathrm{day}$ and NEAP $39.79 \mathrm{mEq} /$ day. The prevalence of overweight and obesity, both in males and females, tended to decrease across tertiles of PRAL and to increase across tertiles of NEAP. In females, the values of several metabolic characteristics differed across tertiles of NEAP. After adjustment for age and waist circumference, these relationships did not persist, but the prevalence of diabetes was found to increase across tertiles of PRAL ( $p$ for trend $<0.05$ ) in females.

Conclusions. The dietary acid load in the Polish adult population was relatively low. There was no independent relationship between dietary acid load and cardiovascular disease and its risk factors in the population under study, except for the positive association between the PRAL value and diabetes prevalence in females.

Key words: cardiovascular risk factors, Polish population, dietary acid load 
The body's acid/base balance is one of the essential factors that influence the human metabolism and thus also health. ${ }^{1,2}$ Its disturbances may negatively affect the organism. Metabolic acidosis seems to foster osteoporosis and renal calculosis. It was also suggested that it may contribute to the development of arterial hypertension, atherosclerosis, diabetes, and cancer. ${ }^{3-8}$

It is widely accepted that diet may influence the body's acid/base balance as consumed nutrients are precursors to nonvolatile acids (hydrogen sulphate that arises from sulfur-containing amino acids, and phosphoric acid from phospholipids) and alkaline substances (cations of potassium, magnesium and calcium). Meat, fish, cheese, cereals, and rice have a relatively high acid-forming potential, while fruits, legumes, vegetables, red wine and potatoes have a base-forming potential. ${ }^{9}$ The Western dietary pattern is characterized by a big share of products of high acid load, which impedes the maintenance of the optimal body acid/base balance, i.e., the lack of acidosis or mild metabolic acidosis. ${ }^{10}$

It is possible to calculate the potential renal acid load (PRAL) of every food item or diet as a whole. A negative PRAL value indicates a base-forming potential of the ingested food, while a positive value points to its acidforming potential. ${ }^{11,12}$

The daily PRAL, along with a relatively constant 24-hour amount of organic acids excreted with urine, which is related to the individual body surface area, contributes to the daily renal net acid excretion. There are 2 methods that enable the evaluation of renal net acid excretion. One of them is a direct measurement in the 24-hour urine collection. The $2^{\text {nd }}$, more practical to be applied in epidemiological studies, relies on calculations using validated formulae that take into account nutrient intake data. There are several available algorithms created for the prediction of the daily net endogenous acid production (NEAP). ${ }^{13}$

Until now, no large epidemiological study that would evaluate the link between the dietary acid load and cardiovascular risk in the Polish population has been performed. The aim of our investigation was to estimate the relationship between dietary acid load and the prevalence and intensity of cardiovascular disease risk factors (i.e., hypertension, diabetes, overweight and obesity, dyslipidemia) and the prevalence of cardiovascular disease (CVD) in the Polish population.

\section{Material and methods}

\section{Study procedure}

The data that was used in the present study came from the Multi-Center National Population Health Examination Survey (WOBASZ II study). The project was carried out by the Institute of Cardiology (Warszawa, Poland), together with 5 medical universities in Poland, in 2013-2014.
The study was accepted by the Bioethics Committee of Institute of Cardiology in Warszawa.

\section{Study population}

The survey included a random sample of inhabitants of the whole Poland aged 20 and above. A total number of 6170 respondents participated in the study; $45.5 \%$ of the sample of available randomized subjects. The details concerning the randomization protocol and participant selection were presented elsewhere. ${ }^{14}$

\section{Laboratory measurements}

Laboratory tests were performed in the Central Laboratory "Diagnostyka" at the Institute of Cardiology in Warszawa, which holds the CDC certificate (Center for Disease Control - Lipid Standardization Program) in Atlanta and the European certificate of quality RIQAS (Random International Quality Assessment Scheme). Measurements of cholesterol and triglycerides, LDL- and HDL-cholesterol, and glucose concentrations were performed. The details concerning blood sampling, transport, and methodology of measurements were described elsewhere. $^{14}$

\section{Assessment of hypertension/ anthropometric measurements}

Blood pressure measurements were performed 3 times at the right arm by means of automatic AND UA-631 devices (A\&D Company Ltd.; R\&D Technical Centre, Saitama, Japan), approved by AAMI (Association for the Advancement of Medical Instrumentation). For the assessment of the blood pressure value, the average from the $2^{\text {nd }}$ and $3^{\text {rd }}$ measurements was taken.

\section{Dietary assessment}

Dietary assessment was performed by skilled nurses using a quantitative interview on the consumption of products and dishes in the period of $24 \mathrm{~h}$ prior to the examination. For a precise assessment of the amount of food consumed, an album developed by the Food and Nutrition Institute in Warsaw with over 200 photographs of the most commonly consumed dishes, products and drinks was used. Additionally, information about taking dietary supplements was collected. In the dietary analysis data from 5690 respondents ( 2554 males and 3136 females) were used, after the rejection of 459 cases $(197$ males and $262 \mathrm{fe}$ males) because of a lack or unreliability of the interview. Based on the conducted interviews, energy and nutritional values of the diets were calculated, using the Polish food composition database. ${ }^{15}$ In the case of vitamins and minerals intakes both with food and dietary supplements were taken into account. 


\section{Calculation of dietary acid load}

Values of PRAL and NEAP were calculated from estimated nutrient intakes ${ }^{3}$ :

1. PRAL $[\mathrm{mEq} /$ day $]=(0.49 \times$ protein $[\mathrm{g} /$ day $])+(0.037 \times$ $\times$ phosphorus $[\mathrm{mg} /$ day $])-(0.021 \times$ potassium $[\mathrm{mg} /$ day $])-$ - $(0.026 \times$ magnesium $[\mathrm{mg} /$ day $])-(0.013 \times$ calcium $[\mathrm{mg} /$ day $])$;

2. $\mathrm{NEAP}[\mathrm{mEq} / \mathrm{day}]=\operatorname{PRAL}[\mathrm{mEq} /$ day $]+\mathrm{OA}_{\text {est }}[\mathrm{mEq} / \mathrm{day}]$.

$\mathrm{OA}_{\text {est }}$ denotes estimated urinary organic anions, calculated according to the formula:

$\mathrm{OA}_{\text {est }}[\mathrm{mEq} /$ day $]=$ individual body surface area $\times 41 / 1.73$

body surface area $\left[\mathrm{m}^{2}\right]=0.007184 \times$ height $[\mathrm{cm}]^{0.725} \times$ $\times$ weight $[\mathrm{kg}]^{0.425}$.

\section{Statistical analysis}

The results were analyzed in 2 steps. In the $1^{\text {st }}$, the tertiles of PRAL and NEAP were defined and the type of distribution of continuous variables were determined (the ShapiroWilk test). The majority of the variables were non-normal. Differences of medians between men and women (Table 1) were tested by the Mann-Whitney-Wilcoxon test. To compare the medians of variables in tertiles of PRAL and NEAP the nonparametric Kruskal-Wallis test for continuous and the $X^{2}$ test for categorized variables were used. In the case of significance, or borderline significance of differences of medians between tertiles, linear trends were analyzed using the Cochran-Armitage test (Tables 2,3). In the $2^{\text {nd }}$ step, comparison of means or frequency, adjusted by age and waist circumference, were tested by using the multivariate analysis of covariance and regression. Likewise, for significantly different adjusted means or frequencies, the linear trends were tested (Tables 4,5). P-values of less than 0.05 were considered statistically significant. Data analyses were processed using Statistical Analysis System (SAS, v. 9.2, SAS Institute Inc., Cary, USA).

Table 1. Median values of the main characteristics of the study participants

\begin{tabular}{|c|c|c|c|c|}
\hline Characteristic & $\begin{array}{c}\text { Total } \\
n=6169\end{array}$ & $\begin{array}{c}\text { Men } \\
n=2760\end{array}$ & $\begin{array}{l}\text { Women } \\
n=3409\end{array}$ & $\mathrm{p}$-value \\
\hline Age [years] & $\begin{array}{c}n=6169 \\
51.00\end{array}$ & $\begin{array}{c}n=2760 \\
49.00\end{array}$ & $\begin{array}{c}n=3409 \\
52.00\end{array}$ & $<0.01$ \\
\hline BMI $\left[\mathrm{kg} / \mathrm{m}^{2}\right]$ & $\begin{array}{c}n=5849 \\
26.57\end{array}$ & $\begin{array}{c}n=2631 \\
27.08\end{array}$ & $\begin{array}{c}n=3218 \\
26.03\end{array}$ & $<0.0001$ \\
\hline Waist circumference [cm] & $\begin{array}{c}n=6005 \\
92.00\end{array}$ & $\begin{array}{c}n=2684 \\
97.00\end{array}$ & $\begin{array}{c}n=3321 \\
87.00\end{array}$ & $<0.0001$ \\
\hline PRAL [mEq/day] & $\begin{array}{c}n=5690 \\
-3.85\end{array}$ & $\begin{array}{c}n=2554 \\
0.88\end{array}$ & $\begin{array}{c}n=3136 \\
-7.10\end{array}$ & $<0.0001$ \\
\hline NEAP [mEq/day] & $\begin{array}{c}n=5394 \\
39.79\end{array}$ & $\begin{array}{c}n=2434 \\
47.55\end{array}$ & $\begin{array}{c}n=2960 \\
34.83\end{array}$ & $<0.0001$ \\
\hline
\end{tabular}

BMI - body mass index; NEAP - net endogenous acid production; PRAL - potential renal acid load.

\section{Results}

The median PRAL and NEAP values for the whole study population were: PRAL $-3.85 \mathrm{mEq} /$ day and NEAP $39.79 \mathrm{mEq} /$ day. Both PRAL and NEAP values were significantly lower in the female than in the male group, similarly to the BMI and waist circumference values (Table 1).

Characteristics of participants, stratified by tertiles of PRAL, are presented in Table 2. There were no significant differences across tertiles regarding the prevalence of smoking habits, CVD, arterial hypertension, diabetes, and lipid abnormalities, as well as laboratory and clamp measurements, except for that of HDL-cholesterol level. Among males there were significantly lower age medians in higher tertiles of PRAL (p-value for trend across tertiles $<0.0001$ ) and in females significantly the lowest medians of BMI and waist circumference in the $3^{\text {rd }}$ tertile of PRAL. The prevalence of overweight and obesity in both males and females tended to decrease across tertiles, with the $\mathrm{p}$ for trend $<0.05$ and $<0.01$, respectively.

Characteristics of participants, stratified by tertiles of NEAP, are shown in Table 3. No significant differences were found across tertiles concerning education level, prevalence of smoking habit, cardiovascular disease, arterial hypertension, and lipid abnormalities, except for that of hypertriglyceridemia in females, with the lowest prevalence in the $1^{\text {st }}$ tertile. In males, HDL-cholesterol level was the lowest, and diastolic blood pressure value the highest (at the borderline of statistical significance) in the highest NEAP tertile. In females the values of systolic and diastolic blood pressure, and also glucose and triglyceride levels were significantly the lowest, and HDL-cholesterol level the highest in the $1^{\text {st }}$ than in the higher tertiles of NEAP.

There were significant differences across tertiles of NEAP concerning age in males and body mass in the both sexes. In males, the age tended to decrease ( $p$ for trend $<0.0001$ ) with the number of tertiles. Both in males and females BMI tended to increase with tertiles of NEAP ( $\mathrm{p}$ for trend $<0.0001$ and $<0.001$ respectively), as well as waist circumferences ( $\mathrm{p}$ for trend $<0.0001$ ). In both sexes, across tertiles of NEAP, the prevalence of overweight and obesity tended to increase ( $p$ for trend $<0.05$ and $<0.001$ respectively). In females, the prevalence of diabetes also tended to increase ( $\mathrm{p}$ for trend $<0.05$ ).

When adjusted for age and waist circumference, there were no significant differences across tertiles, either of PRAL and NEAP, concerning the prevalence of CVD, hypertension, and lipid abnormalities (Tables 4,5 ). In females, the prevalence of diabetes was significantly the highest in the highest tertile of PRAL ( $p$ for trend <0.05). In males the median value of HDL-cholesterol was significantly the lowest in the $1^{\text {st }}$ tertile of PRAL and the mean value of triglycerides the highest in the $2^{\text {nd }}$ tertile of NEAP. The further adjustment for MUFA, PUFA, SFA, and fiber intakes did not reveal any additional significant differences in lipid characteristics across PRAL and NEAP tertiles. 
Table 2. Characteristics of the men and women under study by tertiles of PRAL

\begin{tabular}{|c|c|c|c|c|c|c|c|c|}
\hline \multirow{3}{*}{ Characteristic } & \multicolumn{4}{|c|}{ Men } & \multicolumn{4}{|c|}{ Women } \\
\hline & \multicolumn{3}{|c|}{ PRAL tertiles } & \multirow[b]{2}{*}{$p$-value } & \multicolumn{3}{|c|}{ PRAL tertiles } & \multirow[b]{2}{*}{$\mathrm{p}$-value } \\
\hline & $\begin{array}{c}1 \\
(-182.80 \\
-8.06)\end{array}$ & $\begin{array}{c}2 \\
(-8.05 \\
9.78)\end{array}$ & $\begin{array}{c}3 \\
(9.79 \\
133.06)\end{array}$ & & $\begin{array}{c}1 \\
(-105.58 \\
-13.94)\end{array}$ & $\begin{array}{c}2 \\
(-13.93 \\
0.27)\end{array}$ & $\begin{array}{c}3 \\
(0.28 \\
67.93)\end{array}$ & \\
\hline \multicolumn{9}{|c|}{ median values } \\
\hline PRAL [mEq/day] & -19.55 & 0.87 & 21.75 & $<0.0001$ & -22.36 & -7.11 & 9.27 & $<0.0001$ \\
\hline $\operatorname{NEAP}[\mathrm{mEq} / \mathrm{day}]$ & 27.31 & 47.79 & 70.46 & $<0.0001$ & 18.53 & 34.94 & 51.20 & $<0.0001$ \\
\hline Age [years] & 52.00 & 51.00 & 46.00 & $\begin{array}{l}<0.0001 \\
\text { for trend }<0.0001\end{array}$ & 51.00 & 52.00 & 51.00 & ns \\
\hline $\mathrm{BMI}\left[\mathrm{kg} / \mathrm{m}^{2}\right]$ & 27.24 & 26.86 & 27.08 & ns & 26.30 & 26.54 & 25.70 & $\begin{array}{c}<0.01 \\
\text { for trend }<0.05\end{array}$ \\
\hline Waist circumference [cm] & 97.00 & 96.50 & 96.00 & ns & 87.00 & 87.00 & 86.00 & $\begin{array}{l}<0.05 \\
\text { for trend }<0.05\end{array}$ \\
\hline \multicolumn{9}{|c|}{ Prevalence [\%] } \\
\hline Overweight or obese $e^{a}$ & 71.65 & 68.49 & 66.63 & $\begin{array}{c}0.09 \\
\text { for trend }<0.05\end{array}$ & 60.60 & 59.61 & 56.31 & $\begin{array}{c}0.1 \\
\text { for trend }<0.01\end{array}$ \\
\hline Current smokers & 26.09 & 30.54 & 30.24 & ns & 19.33 & 19.33 & 17.32 & ns \\
\hline $\begin{array}{l}\text { Education } \\
\text { elementary school } \\
\text { secondary school } \\
\text { university or equivalent }\end{array}$ & $\begin{array}{l}46.24 \\
33.65 \\
20.12\end{array}$ & $\begin{array}{l}46.53 \\
37.25 \\
16.22\end{array}$ & $\begin{array}{l}40.71 \\
39.41 \\
19.88\end{array}$ & $<0.05$ & $\begin{array}{l}35.60 \\
38.76 \\
25.65\end{array}$ & $\begin{array}{l}38.79 \\
36.21 \\
25.00\end{array}$ & $\begin{array}{l}34.42 \\
39.98 \\
25.60\end{array}$ & ns \\
\hline Cardiovascular disease $^{b}$ & 15.98 & 14.34 & 13.38 & ns & 10.72 & 11.58 & 12.33 & ns \\
\hline Hypertensionc & 47.96 & 51.07 & 52.25 & ns & 59.13 & 56.33 & 59.48 & ns \\
\hline Diabetes $^{d}$ & 10.36 & 13.19 & 11.12 & ns & 9.24 & 8.23 & 11.26 & 0.06 \\
\hline $\begin{array}{l}\text { Hypercholesterolemiae } \\
\text { High LDL-cholesterol }^{f} \\
\text { Hypertriglyceridemiag } \\
\text { Low HDL-cholesterol }^{h}\end{array}$ & $\begin{array}{l}54.87 \\
57.00 \\
36.86 \\
20.44\end{array}$ & $\begin{array}{l}55.72 \\
55.70 \\
35.22 \\
16.69\end{array}$ & $\begin{array}{l}55.87 \\
56.68 \\
35.97 \\
18.94\end{array}$ & $\begin{array}{l}\text { ns } \\
\text { ns } \\
\text { ns } \\
\text { ns }\end{array}$ & $\begin{array}{l}57.21 \\
51.34 \\
21.81 \\
21.99\end{array}$ & $\begin{array}{l}54.84 \\
51.94 \\
22.95 \\
21.83\end{array}$ & $\begin{array}{l}53.93 \\
49.19 \\
21.47 \\
18.55\end{array}$ & $\begin{array}{l}\text { ns } \\
\text { ns } \\
\text { ns } \\
\text { ns }\end{array}$ \\
\hline \multicolumn{9}{|c|}{ Laboratory and clamp measurements (median values) } \\
\hline Systolic blood pressure [mm Hg] & 132.00 & 131.00 & 131.00 & ns & 124.00 & 124.00 & 123.50 & ns \\
\hline Diastolic blood pressure [mm Hg] & 80.50 & 80.50 & 81.50 & ns & 78.50 & 79.00 & 78.50 & ns \\
\hline Glucose $[\mathrm{mmol} / \mathrm{L}]$ & 5.36 & 5.36 & 5.33 & ns & 5.09 & 5.15 & 5.12 & ns \\
\hline Total cholesterol [mmol/L] & 5.14 & 5.15 & 5.17 & ns & 5.18 & 5.12 & 5.10 & ns \\
\hline LDL-cholesterol [mmol/L] & 3.17 & 3.13 & 3.15 & ns & 3.03 & 3.03 & 2.97 & ns \\
\hline HDL-cholesterol [mmol/L] & 1.24 & 1.31 & 1.26 & $<0.01$ & 1.50 & 1.48 & 1.53 & $<0.05$ \\
\hline Triglycerides [mmol/L] & 1.43 & 1.34 & 1.37 & ns & 1.17 & 1.20 & 1.16 & ns \\
\hline
\end{tabular}

$\mathrm{BMI}$ - body mass index; NEAP - net endogenous acid production; ns - not statistically significant; PRAL - potential renal acid load; a BMI $\geq 25.0 \mathrm{~kg} / \mathrm{m}^{2}$; ${ }^{b}$ the subject declared hospitalization because of heart infarction, coronary heart disease, heart failure, stroke, arterial fibrillation or other arrhythmias, coronary artery angioplasty or bypass, or if a pacemaker was used; ' systolic blood pressure $\geq 140 \mathrm{~mm} \mathrm{Hg}$ and/or diastolic blood pressure $\geq 90 \mathrm{~mm} \mathrm{Hg}$ or antihypertensive drug treatment; ${ }^{d}$ fasting glucose $\geq 7 \mathrm{mmol} / \mathrm{L}$ and/or previous diagnosis of diabetes; ${ }^{e}$ total $\mathrm{Cholesterol} \geq 5.0 \mathrm{mmol} / \mathrm{L} ;{ }^{f} \mathrm{LDL}-\mathrm{cholesterol}$ $\geq 3.0 \mathrm{mmol} / \mathrm{L} ;{ }^{9}$ triglycerides $>1.7 \mathrm{mmol} / \mathrm{L} ;{ }^{\mathrm{h}} \mathrm{HDL}$-cholesterol $<1.0 \mathrm{mmol} / \mathrm{L}$ for men, HDL-cholesterol $<1.2 \mathrm{mmol} / \mathrm{L}$ for women or hipolipidemic drug treatment.

\section{Discussion}

Similar to our findings were those obtained in the prospective cohort study performed in 2241 older Dutch adults (aged $\geq 55$ years), where the median dietary acid load ranged from -14.6 to $19.9 \mathrm{mEq} /$ day across categories of PRAL, and from 31.7 to $40.5 \mathrm{mEq} /$ day across categories of NEAP. ${ }^{12}$ However, a higher dietary acid load was found in the E3N-EPIC cohort study (66,485 women) where median PRAL was $-3.0 \mathrm{mEq} /$ day (ranged from -23.0 to $14.3 \mathrm{mEq} /$ day) and NEAP ranged from 31.5 to $58.2 \mathrm{mEq} /$ day, ${ }^{5}$ as well as in the prospective cohort study of 87,293 women (The Nurses' Health Study II) where dietary acid load ranged from 34.4 to $76.0 \mathrm{mEq} /$ day across categories of NEAP. ${ }^{16}$ Also, in the studies performed in the Japanese populations the dietary acid load was more acidic than in our subjects. In a group of female students of dietetics $(n=1136)$ the median of PRAL was $10.4 \mathrm{mEq} /$ day (ranged from $-0.8 \mathrm{mEq} /$ day to $19.5 \mathrm{mEq} /$ day), ${ }^{17}$ and in the Furukawa employees $(\mathrm{n}=2028)$ the median PRAL was $9.0 \mathrm{mEq} /$ day $(3.6-13.6 \mathrm{mEq} /$ day) and NEAP 52.1 $\left(45.3-60.0 \mathrm{mEq} /\right.$ day). ${ }^{3}$ 
Table 3. Characteristics of the men and women under study by tertiles of NEAP

\begin{tabular}{|c|c|c|c|c|c|c|c|c|}
\hline \multirow[b]{3}{*}{ Characteristic } & \multicolumn{4}{|c|}{ Men } & \multicolumn{4}{|c|}{ Women } \\
\hline & \multicolumn{3}{|c|}{ NEAP tertiles } & \multirow[b]{2}{*}{$p$-value } & \multicolumn{3}{|c|}{ NEAP tertiles } & \multirow[b]{2}{*}{$\mathrm{p}$-value } \\
\hline & $\begin{array}{c}1 \\
(-133.630 \\
38.556)\end{array}$ & $\begin{array}{c}2 \\
(38.566 \\
57.480)\end{array}$ & $\begin{array}{c}3 \\
(57.481 \\
184.800)\end{array}$ & & $\begin{array}{c}1 \\
(-66.445 \\
27.480)\end{array}$ & $\begin{array}{c}2 \\
(27.481 ; \\
42.040)\end{array}$ & $\begin{array}{c}3 \\
(42.041 \\
115.110)\end{array}$ & \\
\hline \multicolumn{9}{|c|}{ Median values } \\
\hline PRAL [mEq/day] & -19.83 & 0.49 & 22.01 & $<0.0001$ & -22.45 & -7.12 & 9.28 & $<0.0001$ \\
\hline NEAP [mEq/day] & 27.18 & 47.53 & 70.38 & $<0.0001$ & 18.46 & 34.83 & 51.20 & $<0.0001$ \\
\hline Age [years] & 52.00 & 51.00 & 45.00 & $\begin{array}{l}<0.0001 \\
\text { for trend }<0.0001\end{array}$ & 51.00 & 52.00 & 51.00 & ns \\
\hline $\mathrm{BMI}\left[\mathrm{kg} / \mathrm{m}^{2}\right]$ & 26.73 & 26.87 & 27.62 & $\begin{array}{c}<0.0001 \\
\text { for trend }<0.0001\end{array}$ & 25.39 & 26.60 & 26.49 & $\begin{array}{c}<0.0001 \\
\text { for trend }<0.001\end{array}$ \\
\hline Waist circumference [cm] & 96.00 & 97.00 & 98.00 & $\begin{array}{c}<0.001 \\
\text { for trend }<0.0001\end{array}$ & 85.00 & 87.00 & 88.00 & $\begin{array}{c}<0.0001 \\
\text { for trend }<0.0001\end{array}$ \\
\hline \multicolumn{9}{|c|}{ Prevalence [\%] } \\
\hline Overweight or obesitya & 66.71 & 68.56 & 71.55 & $\begin{array}{c}0.1 \\
\text { for trend }<0.05\end{array}$ & 53.55 & 60.79 & 62.21 & $\begin{array}{l}<0.001 \\
\text { for trend } 0.001\end{array}$ \\
\hline Current smokers & 27.62 & 31.56 & 28.36 & ns & 20.69 & 18.26 & 17.83 & ns \\
\hline $\begin{array}{l}\text { Education } \\
\text { elementary school } \\
\text { secondary school } \\
\text { university or equivalent }\end{array}$ & $\begin{array}{l}47.78 \\
32.59 \\
19.63\end{array}$ & $\begin{array}{l}45.25 \\
37.98 \\
16.77\end{array}$ & $\begin{array}{l}39.01 \\
40.25 \\
20.74\end{array}$ & ns & $\begin{array}{l}34.79 \\
39.45 \\
25.76\end{array}$ & $\begin{array}{l}38.03 \\
37.02 \\
24.95\end{array}$ & $\begin{array}{l}35.37 \\
39.43 \\
25.20\end{array}$ & ns \\
\hline Cardiovascular disease $^{b}$ & 16.52 & 13.44 & 13.18 & ns & 10.95 & 11.55 & 12.66 & ns \\
\hline Hypertension ${ }^{c}$ & 48.81 & 50.69 & 51.74 & ns & 61.21 & 56.70 & 56.70 & ns \\
\hline Diabetes $^{d}$ & 11.15 & 11.51 & 11.50 & ns & 8.47 & 8.95 & 11.33 & $\begin{array}{c}0.07 \\
\text { for trend }<0.05\end{array}$ \\
\hline $\begin{array}{l}\text { Hypercholesterolemiae } \\
\text { High LDL-cholesterol }^{f} \\
\text { Hypertriglyceridemiag }^{\text {to }} \\
\text { Low HDL-cholesterol }^{\text {h }}\end{array}$ & $\begin{array}{l}54.60 \\
57.49 \\
34.44 \\
18.41\end{array}$ & $\begin{array}{l}56.65 \\
55.84 \\
36.19 \\
17.46\end{array}$ & $\begin{array}{l}55.64 \\
56.56 \\
\\
37.44 \\
19.28\end{array}$ & $\begin{array}{l}\text { ns } \\
\text { ns } \\
\text { ns } \\
\text { ns }\end{array}$ & $\begin{array}{l}55.94 \\
49.95 \\
\\
18.82 \\
19.14\end{array}$ & $\begin{array}{l}56.56 \\
52.71 \\
24.53 \\
22.40\end{array}$ & $\begin{array}{l}54.96 \\
50.05 \\
22.33 \\
20.42\end{array}$ & $\begin{array}{c}\text { ns } \\
\text { ns } \\
<0.01 \\
\text { for trend }=0.06 \\
\text { ns }\end{array}$ \\
\hline \multicolumn{9}{|c|}{ Laboratory and clamp measurements (median values) } \\
\hline Systolic blood pressure [mm Hg] & 131.00 & 131.50 & 131.00 & ns & 122.50 & 125.00 & 124.00 & $\begin{array}{c}<0.05 \\
\text { for trend }<0.05\end{array}$ \\
\hline Diastolic blood pressure [mm Hg] & 80.00 & 80.50 & 82.00 & ns & 77.50 & 79.00 & 79.00 & $\begin{array}{c}<0.05 \\
\text { for trend }<0.05\end{array}$ \\
\hline Glucose $[\mathrm{mmol} / \mathrm{L}]$ & 5.37 & 5.33 & 5.33 & ns & 5.07 & 5.15 & 5.14 & $\begin{array}{l}<0.01 \\
\text { for trend }<0.01\end{array}$ \\
\hline Total cholesterol [mmol/L] & 5.14 & 5.20 & 5.14 & ns & 5.17 & 5.16 & 5.11 & ns \\
\hline LDL-cholesterol [mmol/L] & 3.17 & 3.15 & 3.14 & ns & 2.99 & 3.06 & 3.00 & ns \\
\hline HDL-cholesterol [mmol/L] & 1.28 & 1.30 & 1.25 & $<0.05$ & 1.54 & 1.48 & 1.51 & $<0.05$ \\
\hline Triglycerides [mmol/L] & 1.36 & 1.37 & 1.39 & ns & 1.13 & 1.22 & 1.18 & $\begin{array}{c}<0.05 \\
\text { for trend }=0.06\end{array}$ \\
\hline
\end{tabular}

$\mathrm{BMI}$ - body mass index; NEAP - net endogenous acid production; ns - not statistically significant; PRAL - potential renal acid load; a BMI $\geq 25.0 \mathrm{~kg} / \mathrm{m}^{2}$; ${ }^{b}$ the subject declared hospitalization because of heart infarction, coronary heart disease, heart failure, stroke, arterial fibrillation or other arrhythmias, coronary artery angioplasty or bypass, or if a pacemaker was used; ' systolic blood pressure $\geq 140 \mathrm{~mm} \mathrm{Hg}$ and/or diastolic blood pressure $\geq 90 \mathrm{~mm} \mathrm{Hg}$ or antihypertensive drug treatment; ${ }^{d}$ fasting glucose $\geq 7 \mathrm{mmol} / \mathrm{L}$ and/or previous diagnosis of diabetes; ${ }^{e}$ total cholesterol $\geq 5.0 \mathrm{mmol} / \mathrm{L} ;{ }^{f} \mathrm{LDL}-\mathrm{cholesterol}$ $\geq 3.0 \mathrm{mmol} / \mathrm{L} ;{ }^{9}$ triglycerides $>1.7 \mathrm{mmol} / \mathrm{L} ;{ }^{h} \mathrm{HDL}$-cholesterol $<1.0 \mathrm{mmol} / \mathrm{L}$ for men, HDL-cholesterol $<1.2 \mathrm{mmol} / \mathrm{L}$ for women or hipolipidemic drug treatment.

In our study, higher values of PRAL were accompanied by a higher consumption of acidifying foods, and lower consumption of alkalinizing foods. In the additional analysis, performed for the requirement of this discussion, the level of consumption of acid-forming foods across PRAL tertiles tended to increase as follows: meat and meat products (men: from 116.0 to $160.0 \mathrm{~g} /$ day), eggs (men: from 5.75 to $12.25 \mathrm{~g} /$ day; women: from 3.0 to $6.75 \mathrm{~g} /$ day), grains (men: from 148.0 to $204.82 \mathrm{~g} /$ day; women: from 107.9 to $138.0 \mathrm{~g} /$ day), and alcohol (only in males from 4.35 to $6.65 \mathrm{~g} /$ day). Simultaneously, consumption of vegetables and fruits tended to decrease. In males, the intake 
Table 4. Prevalence of cardiovascular disease, hypertension, lipid abnormalities, and diabetes and median values of cardiovascular risk factors by tertiles of PRAL in males and females, adjusted for age and waist circumference

\begin{tabular}{|c|c|c|c|c|c|c|c|c|}
\hline \multirow{3}{*}{ Characteristic } & \multicolumn{4}{|c|}{ Men } & \multicolumn{4}{|c|}{ Women } \\
\hline & \multicolumn{3}{|c|}{ PRAL tertiles } & \multirow[b]{2}{*}{$\mathrm{p}$-value } & \multicolumn{3}{|c|}{ PRAL tertiles } & \multirow[b]{2}{*}{$\mathrm{p}$-value } \\
\hline & $\begin{array}{c}1 \\
(-182.80 \\
-8.06)\end{array}$ & $\begin{array}{c}2 \\
(-8.05 \\
9.78)\end{array}$ & $\begin{array}{c}3 \\
(9.79 \\
133.06)\end{array}$ & & $\begin{array}{c}1 \\
(-105.58 \\
-13.94)\end{array}$ & $\begin{array}{c}2 \\
(-13.93 \\
0.27)\end{array}$ & $\begin{array}{c}3 \\
(0.28 \\
67.93)\end{array}$ & \\
\hline Cardiovascular disease ${ }^{a}[\%]$ & 14.8 & 13.1 & 14.9 & ns & 10.4 & 11.0 & 12.8 & ns \\
\hline Hypertension ${ }^{\mathrm{b}}[\%]$ & 50.3 & 47.4 & 50.8 & ns & 41.1 & 42.8 & 42.0 & ns \\
\hline Diabetes ${ }^{c}[\%]$ & 9.7 & 12.7 & 12.2 & ns & 9.1 & 8.0 & 11.7 & $\begin{array}{c}0.01 \\
\text { for trend }<0.05\end{array}$ \\
\hline $\begin{array}{l}\text { Hypercholesterolemiad } \\
\text { High LDL-cholesterol }^{\mathrm{e}} \\
\text { Hypertriglyceridemia }^{f} \\
\text { Low HDL-cholesterol }^{g}\end{array}$ & $\begin{array}{l}54.5 \\
56.8 \\
36.6 \\
20.2\end{array}$ & $\begin{array}{l}54.9 \\
55.7 \\
35.8 \\
17.0\end{array}$ & $\begin{array}{l}56.8 \\
57.5 \\
35.0 \\
18.3\end{array}$ & $\begin{array}{l}\text { ns } \\
\text { ns } \\
\text { ns } \\
\text { ns }\end{array}$ & $\begin{array}{l}57.0 \\
51.1 \\
21.2 \\
21.9\end{array}$ & $\begin{array}{l}54.7 \\
51.6 \\
22.2 \\
21.8\end{array}$ & $\begin{array}{l}53.6 \\
49.2 \\
21.6 \\
19.0\end{array}$ & $\begin{array}{l}\text { ns } \\
\text { ns } \\
\text { ns } \\
\text { ns }\end{array}$ \\
\hline Systolic blood pressure [mm Hg] & 134.1 & 134.7 & 134.5 & ns & 127.4 & 127.6 & 128.2 & ns \\
\hline Diastolic blood pressure [mm Hg] & 81.2 & 81.3 & 82.0 & ns & 79.3 & 79.4 & 79.2 & ns \\
\hline Glucose $[\mathrm{mmol} / \mathrm{L}]$ & 5.58 & 5.70 & 5.64 & ns & 5.35 & 5.38 & 5.45 & ns \\
\hline Total cholesterol [mmol/L] & 5.16 & 5.23 & 5.20 & ns & 5.21 & 5.15 & 5.19 & ns \\
\hline LDL-cholesterol [mmol/L] & 3.19 & 3.16 & 3.22 & ns & 3.13 & 3.07 & 3.10 & ns \\
\hline HDL-cholesterol [mmol/L] & 1.30 & 1.36 & 1.33 & $<0.05$ & 1.53 & 1.52 & 1,55 & ns \\
\hline Triglycerides [mmol/L] & 1.70 & 1.87 & 1.70 & ns & 1.35 & 1.35 & 1.35 & ns \\
\hline
\end{tabular}

ns - not statistically significant; PRAL - potential renal acid load; ${ }^{a}$ the subject declared hospitalization because of heart infarction, coronary heart disease, heart failure, stroke, arterial fibrillation or other arrhythmias, coronary artery angioplasty or bypass, or if a pacemaker was used; ${ }^{b}$ systolic blood pressure $\geq 140 \mathrm{~mm} \mathrm{Hg}$ and/or diastolic blood pressure $\geq 90 \mathrm{~mm} \mathrm{Hg}$ or antihypertensive drug treatment; ${ }^{c}$ fasting glucose $\geq 7 \mathrm{mmol} / \mathrm{L}$ and/or previous diagnosis of diabetes; ${ }^{d}$ total cholesterol $\geq 5.0 \mathrm{mmol} / \mathrm{L} ;{ }^{\mathrm{e}} \mathrm{LDL}$-cholesterol $\geq 3.0 \mathrm{mmol} / \mathrm{L} ;{ }^{f}$ triglycerides $>1.7 \mathrm{mmol} / \mathrm{L} ;{ }^{9} \mathrm{HDL}$-cholesterol $<1.0 \mathrm{mmol} / \mathrm{L}$ for $\mathrm{men}$, $\mathrm{HDL}$-cholesterol $<1.2 \mathrm{mmol} / \mathrm{L}$ for women or hipolipidemic drug treatment.

Table 5. Prevalence of cardiovascular disease, hypertension, lipid abnormalities, and diabetes and median values of cardiovascular risk factors by tertiles of NEAP in males and females, adjusted for age and waist circumference

\begin{tabular}{|c|c|c|c|c|c|c|c|c|}
\hline \multirow{3}{*}{ Characteristic } & \multicolumn{4}{|c|}{ Men } & \multicolumn{4}{|c|}{ Women } \\
\hline & \multicolumn{3}{|c|}{ NEAP tertiles } & \multirow[b]{2}{*}{$p$-value } & \multicolumn{3}{|c|}{ NEAP tertiles } & \multirow[b]{2}{*}{$\mathrm{p}$-value } \\
\hline & $\begin{array}{c}1 \\
(-133.630 \\
38.556)\end{array}$ & $\begin{array}{c}2 \\
(38.566 ; \\
57.480)\end{array}$ & $\begin{array}{c}3 \\
(57.481 \\
184.800)\end{array}$ & & $\begin{array}{c}1 \\
(-66.445 \\
27.480)\end{array}$ & $\begin{array}{c}2 \\
(27.481 ; \\
42.040)\end{array}$ & $\begin{array}{c}3 \\
(42.041 \\
115.110)\end{array}$ & \\
\hline Cardiovascular disease $\left.{ }^{a} \%\right]$ & 15.3 & 12.8 & 15.1 & ns & 11.0 & 11.3 & 12.6 & ns \\
\hline Hypertension ${ }^{b}[\%]$ & 50.0 & 48.2 & 50.6 & ns & 41.2 & 42.7 & 42.6 & ns \\
\hline Diabetesc [\%] & 10.9 & 11.0 & 12.5 & ns & 9.5 & 8.7 & 10.7 & ns \\
\hline $\begin{array}{l}\text { Hypercholesterolemiad [\%] } \\
\text { High LDL-cholesterole [\%] } \\
\text { Hypertriglyceridemia }{ }^{\mathrm{f}}[\%] \\
\text { Low HDL-cholesterol }^{\mathrm{g}}[\%]\end{array}$ & $\begin{array}{l}53.7 \\
57.3 \\
36.3 \\
19.7\end{array}$ & $\begin{array}{l}56.2 \\
55.8 \\
36.2 \\
17.3\end{array}$ & $\begin{array}{l}56.5 \\
56.8 \\
35,2 \\
17.8\end{array}$ & $\begin{array}{l}\text { ns } \\
\text { ns } \\
\text { ns } \\
\text { ns }\end{array}$ & $\begin{array}{l}55.9 \\
50.5 \\
20.6 \\
20.5\end{array}$ & $\begin{array}{l}56.3 \\
52.5 \\
24.0 \\
22.2\end{array}$ & $\begin{array}{l}54.0 \\
49.6 \\
20.9 \\
19.5\end{array}$ & $\begin{array}{l}\text { ns } \\
\text { ns } \\
\text { ns } \\
\text { ns }\end{array}$ \\
\hline Systolic blood pressure [mm Hg] & 134.1 & 134.6 & 134.5 & ns & 126.9 & 128.1 & 127.9 & ns \\
\hline Diastolic blood pressure [mm Hg] & 81.2 & 81.5 & 82.0 & ns & 78.9 & 79.7 & 79.2 & ns \\
\hline Glucose $[\mathrm{mmol} / \mathrm{L}]$ & 5.60 & 5.69 & 5.63 & ns & 5.36 & 5.37 & 5.43 & ns \\
\hline Total cholesterol [mmol/L] & 5.15 & 5.26 & 5.18 & ns & 5.20 & 5.19 & 5.19 & ns \\
\hline LDL-cholesterol [mmol/L] & 3.18 & 3.20 & 3.19 & ns & 3.12 & 3.10 & 3.11 & ns \\
\hline HDL-cholesterol [mmol/L] & 1.31 & 1.35 & 1.34 & ns & 1.53 & 1.52 & 1.54 & ns \\
\hline Triglycerides [mmol/L] & 1.68 & 1.91 & 1.70 & $<0.05$ & 1.33 & 1.38 & 1.34 & ns \\
\hline
\end{tabular}

NEAP - net endogenous acid production; ns - not statistically significant; a the subject declared hospitalization because of heart infarction, coronary heart disease, heart failure, stroke, arterial fibrillation or other arrhythmias, coronary artery angioplasty or bypass, or if a pacemaker was used; b systolic blood pressure $\geq 140 \mathrm{~mm} \mathrm{Hg}$ and/or diastolic blood pressure $\geq 90 \mathrm{~mm} \mathrm{Hg}$ or antihypertensive drug treatment; ${ }^{c}$ fasting glucose $\geq 7 \mathrm{mmol} / \mathrm{L}$ and/or previous diagnosis of diabetes; ${ }^{d}$ total cholesterol $\geq 5.0 \mathrm{mmol} / \mathrm{L} ;{ }^{\mathrm{e}} \mathrm{LDL}$-cholesterol $\geq 3.0 \mathrm{mmol} / \mathrm{L} ;{ }^{f}$ triglycerides $>1.7 \mathrm{mmol} / \mathrm{L} ;{ }^{9} \mathrm{HDL}-\mathrm{cholesterol}<1.0 \mathrm{mmol} / \mathrm{L}$ for $\mathrm{men}$, $\mathrm{HDL}$-cholesterol $<1.2 \mathrm{mmol} / \mathrm{L}$ for women or hipolipidemic drug treatment. 
of vegetables declined from 300.0 to $188.9 \mathrm{~g} / \mathrm{day}$, and of fruits from 200.0 to $50.0 \mathrm{~g} /$ day, while in females consumption of vegetables dropped from 268.0 to $50.8 \mathrm{~g} /$ day and that of fruits from 250.0 to $129.4 \mathrm{~g} /$ day.

It was found that males in higher tertiles of PRAL were significantly younger ( $\mathrm{p}$ for trend $<0.0001$ ). This suggests that younger males tend to consume a less healthy diet. Nevertheless, a detailed analysis of food consumption in age groups has not been performed yet.

We observed that females in the higher tertiles of PRAL tended to be characterized by lower adiposity, measured by both BMI and waist circumference values. The prevalence of overweight and obesity tended to decrease with tertiles of PRAL in both sexes. It may be assumed that this resulted from a higher intake of protein in the higher tertiles of PRAL. In males it tended to increase from 68.1 to $100.1 \mathrm{~g} / \mathrm{day}$, and in females from 53.3 to $68.2 \mathrm{~g} /$ day, ( $\mathrm{p}<0.0001)$. Protein is known as a dietary factor that may suppress appetite and contribute to weight loss. ${ }^{18}$ Additionally, males in the higher PRAL tertiles were younger, which may also explains the tendency towards a lower prevalence of overweight and obesity in higher PRAL male groups.

The probable influence of acid-base homeostasis on cardiovascular risk was suggested by other investigators. It seems that diet-induced acidosis may contribute to the elevation of blood pressure. The proposed mechanisms are: increased cortisol production, increased calcium, and decreased citrate excretion. The raised cortisol secretion related to mild metabolic acidosis was postulated to exacerbate also other metabolic risk factors. ${ }^{17}$

To our knowledge, this is the $1^{\text {st }}$ study to examine the relationships between dietary acid-base load measures and cardiovascular risk factors in the Polish population. We did not observe any relevant differences regarding metabolic characteristics across tertiles of either PRAL and NEAP in males. Likewise, there were no essential findings in females, except of the observation that prevalence of diabetes was independently associated with PRAL. It tended to increase across tertiles of PRAL ( $p$ for trend $<0.05$ ).

Similarly as in our investigation, in the Rotterdam Study there was no relationship between dietary acid-base potential and prevalence of arterial hypertension and also other cardiovascular risk factors. This could be explained by a relatively low dietary acid-forming potential in both populations. ${ }^{12}$ On the other hand, in the Nurses' Health Study II, it was shown that high values of NEAP were independently associated with a higher risk of hypertension. The association between estimated NEAP and the risk of hypertension was stronger among lean women $\left(\mathrm{BMI}<25 \mathrm{~kg} / \mathrm{m}^{2}\right) .{ }^{16}$ Likewise, in the investigation preformed in female Japanese dietetic students, higher dietary acid load, expressed by PRAL, was associated with higher systolic and diastolic blood pressure after adjustment for possible confounding factors. It was also shown that there were independent positive associations between PRAL and total and LDL serum cholesterol level, as well as with BMI and waist circumference values. ${ }^{17}$

Our finding concerning the lack of the relationship between the dietary acid load and prevalence of diabetes in males is in accordance with the results of the observational prospective study, done by $\mathrm{Hu}$ et al. that involved 911 non-diabetic Swedish men aged 70-71 years, and did not show any link between dietary acid load and insulin sensitivity, beta cell function or risk of type 2 diabetes. ${ }^{19}$ In our study the prevalence of diabetes was independently associated only with PRAL in females. Also, in the investigation performed by Fagherazzi et al., it was shown in a large sample of 66,485 women that high values of PRAL, and also NEAP, were linked to increased risk of type 2 diabetes. ${ }^{5}$

The mechanism underlying the putative association between dietary acid load and type 2 diabetes is not fully understood as there are few studies dedicated to this problem. Anyway, there are some mechanisms that could explain this possible relationship. Chronic metabolic acidosis, resulting from high dietary acid load, may probably contribute to insulin resistance and metabolic syndrome, which was suggested by cross-sectional studies, an also confirmed by an interventional study in humans. ${ }^{20-23}$ Furthermore, in an animal model, metabolic acidosis impaired the binding of insulin to its receptors, which supported the hypothesis that metabolic acidosis may foster insulin resistance. ${ }^{24}$ Moreover, in experimental studies, acid/base alterations were associated with decreased insulin secretion. ${ }^{25}$ Inhibition of the insulin signaling pathway and increased hepatic gluconeogenesis are also discussed as possible mechanisms linking metabolic acidosis with diabetes risk. ${ }^{26}$ However, the evidence for both, the existence of the relationship between dietary acid load and risk of type 2 diabetes, and also mechanisms underlying this potential association, is very weak.

Our study has some strengths and limitations. Among strengths we can list the following: the large (over 6000 participants), cross-sectional, randomly selected sample of the Polish population, inclusion of nutrient intake from dietary supplements into the analysis, and anthropometric and clamp measurements that were not self-reported, but performed by a professional staff. However, there were also several limitations. First of all, the cross-sectional design does not allow for the assessment of causality owing to the uncertain temporality of the association. Dietary data came from 24-hour recall, which is not considered to be representative for habitual diet at the individual level. Moreover, the misreporting of dietary intake, especially in overweight subjects, is a serious problem for precise dietary assessment. ${ }^{27}$ There was no information about renal function, which plays a pivotal role in acid-base homeostasis. And lastly, PRAL and NEAP values were not measured directly, but estimated from self-reported dietary 24-hour intake. Nevertheless, dietary PRAL and NEAP scores are widely used in large sample studies and highly correlate with acid load measured from 24-hour urine. ${ }^{1,28}$ 


\section{Conclusions}

The dietary acid load in the adult Polish population was relatively low. It was lower in females than in males. There was no independent relationship between dietary acid load and CVD or cardiovascular risk factors in the population under study, except for the positive association between the PRAL value and diabetes prevalence in females.

\section{References}

1. Remer T, Dimitriou T, Manz F. Dietary potential renal acid load and renal net acid excretion in healthy, free-living children and adolescents. Am J Clin Nutr. 2003;77:1255-1260.

2. Manz F. History of nutrition and acid-base physiology. Eur J Nutr. 2001;40:189-199.

3. Akter S, Eguchi M, Kurotani K, et al. High dietary acid load is associated with increased prevalence of hypertension: The Furukawa Nutrition and Health Study. Nutrition. 2015;31:298-303.

4. Adeva MM, Souto G. Diet-induced metabolic acidosis. Clin Nutr. 2011; 30:416-421.

5. Fagherazzi G, Vilier A, Bonnet F, et al. Dietary acid load and risk of type 2 diabetes: The E3N-EPIC cohort study. Diabetologia. 2014;57: 313-320.

6. Tylavsky FA, Spence LA, Harkness L. The importance of calcium potassium, and acid-base homeostasis in bone health and osteoporosis prevention. J Nutr. 2008;138:164-165.

7. Robey IF. Examining the relationship between diet-induced acidosis and cancer. Nutr Metab. 2012;9:72. doi: 10.1186/1743-7075-9-72

8. Trinchieri A, Maletta A, Lizzano R, Marchesotti F. Potential renal acid load and the risk of renal stone formation in a case-control study. Eur J Clin Nutr. 2013;67:1077-1080.

9. Remer T, Manz F. Potential renal acid load of foods and its influence on urine pH. J Am Diet Assoc. 1995;95:791-797.

10. Frassetto L, Morris RC Jr, Sellmeyer DE, Todd K, Sebastian A. Diet, evolution and aging-the pathophysiologic effects of the post-agricultural inversion of the potassium-to-sodium and base-to-chloride ratios in the human diet. Eur J Nutr. 2001;40:200-213.

11. Remer T. Influence of diet on acid-base balance. Semin Dial. 2000;13: 221-226.

12. Engberink MF, Bakker SJ, Brink EJ, et al. Dietary acid load and risk of hypertension: The Rotterdam Study. Am J Clin Nutr. 2012;95: 1438-1444.
13. Frassetto LA, Lanham-New SA, Macdonald HM, Remer T. Standardizing terminology for estimating the diet-dependent net acid load to the metabolic system. J Nutr. 2007;137:1491-1492.

14. Drygas W, Niklas A, Piwońska A, et al. Multi-center National Population Health Examination Survey (WOBASZ II study): Assumptions, methods and implementation. Kardiol Pol. 2016;74(7):681-690.

15. Kunachowicz H, Nadolna I, Przygoda B, Iwanow K. Food Composition Tables. Warszawa: PZWL; 2005.

16. Zhang L, Curhan GC, Forman JP. Diet-dependent net acid load and risk of incident hypertension in United States women. Hypertens. 2009;54:751-755.

17. Murakami K, Sasaki S, Takahashi Y, Uenishi K. Japan Dietetic Students' Study for Nutrition and Biomarkers Group: Association between dietary acid-base load and cardiometabolic risk factors in young Japanese women. BrJ Nutr. 2008,100:642-651.

18. Astrup $A$. The satiating power of protein $-A$ key to obesity prevention? Am J Clin Nutr. 2005;82:1-2.

19. Xu H, Jia T, Huang $X$, et al. Dietary acid load, insulin sensitivity and risk of type 2 diabetes in community-dwelling older men. Diabetologia. 2014;57:156-1568.

20. Cameron MA, Maalouf NM, Adams-Huet B, Moe OW, Sakhaee K. Urine composition in type 2 diabetes: Predisposition to uric acid nephrolithiasis. J Am Soc Nephrol. 2006;17:1422-1428.

21. Maalouf NM, Cameron MA, Moe OW, Adams-Huet B, Sakhaee K. Low urine $\mathrm{pH}$ : A novel feature of the metabolic syndrome. Clin J Am Soc Nephrol. 2007;2:883-888.

22. Souto G, Donapetry C, Calvino J, Adeva MM. Metabolic acidosisinduced insulin resistance and cardiovascular risk. Metab Syndr Relat Disord. 2011;9:247-253.

23. DeFronzo RA, Beckles AD. Glucose intolerance following chronic metabolic acidosis in man. Am J Physiol. 1979;236:328-334.

24. Whittaker J, Cuthbert C, Hammond VA, Alberti KG. The effects of metabolic acidosis in vivo on insulin binding to isolated rat adipocytes. Metabolism. 1982;31:553-557.

25. Rebolledo OR, Hernandez RE, Zanetta AC, Gagliardino JJ. Insulin secretion during acid-base alterations. Am J Physiol. 1978;234: 426-429.

26. Williams RS, Kozan P, Samocha-Bonet D. The role of dietary acid load and mild metabolic acidosis in insulin resistance in humans. Biochimie. 2016;124:171-177. doi: 10.1016/j.biochi.2015.09.012

27. Livingstone MBE, Black AE. Markers of the validity of reported energy intake. J Nutr. 2003;133:895-920.

28. Frassetto LA, Todd KM, Morris RC Jr, Sebastian A. Estimation of net endogenous noncarbonic acid production in humans from diet potassium and protein contents. Am J Clin Nutr. 1998;68:576-583 